Europäisches Spitalwesen

Institutionelle Fürsorge in Mittelalter und Früher Neuzeit

Hospitals and Institutional Care in Medieval and

Early Modern Europe 
Mitteilungen des Instituts

für Österreichische Geschichtsforschung

Ergänzungsband 51

IOG

R. Oldenbourg Verlag Wien München 


\section{Europäisches Spitalwesen. Institutionelle Fürsorge in Mittelalter und Früher Neuzeit \\ Hospitals and Institutional Care in Medieval and Early Modern Europe}

Herausgegeben von

Martin Scheutz, Andrea Sommerlechner, Herwig Weigl, Alfred Stefan Weiß

R. Oldenbourg Verlag Wien München 2008 
Bibliografische Information der Deutschen Nationalbibliothek

Die Deutsche Nationalbibliothek verzeichnet diese Publikation in der Deutschen Nationalbibliografie; detaillierte

Daten sind im Internet über http://dnb.ddb.de abrufbar.

(C) 2008 Oldenbourg Verlag im Veritas Bildungsverlag, Wien

Das Werk ist urheberrechtlich geschützt. Die dadurch begründeten Rechte, insbesondere die der Übersetzung, des Nachdrucks, der Entnahme von Abbildungen, der Funksendung, der Wiedergabe auf photomechanischem oder ähnlichem Wege und der Speicherung in Datenverarbeitungsanlagen, bleiben, auch bei nur auszugsweiser Verwertung, vorbehalten.

Satz: Josef Pauser, Wien

Druck: Grasl Druck \& Neue Medien, A-2540 Bad Vöslau

Umschlaggestaltung: Dieter Vollendorf

Umschlagabbildung: Pürschgerichtskarte von 1564, Stadtarchiv Rottweil. Mit freundlicher Genehmigung des Stadtarchivs Rottweil.

ISBN: 978-3-7029-0558-3 Oldenbourg Verlag im Veritas Bildungsverlag Wien

ISBN: 978-3-486-58566-7 Oldenbourg Wissenschaftsverlag München

ISSN 1817-8774 


\section{Inhalt}

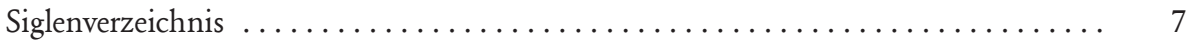

Einleitung / Introduction $\ldots \ldots \ldots \ldots \ldots \ldots \ldots \ldots \ldots \ldots \ldots \ldots \ldots \ldots \ldots \ldots$

Christina VAnja, Offene Fragen und Perspektiven der Hospitalgeschichte . . . . . . . . 19

Brigitte RESL, Hospitals in Medieval England $\ldots \ldots \ldots \ldots \ldots \ldots \ldots \ldots \ldots \ldots$

Ian W. ArCHER, Hospitals in Sixteenth- and Seventeenth-Century England . . . . . . . 53

Daniel Hickey, Institutionalized Care for the Sick and the Poor in Early Modern

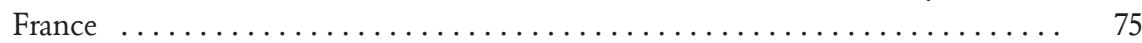

Gisela Drossbach, Hospitäler im Patrimonium Petri $\ldots \ldots \ldots \ldots \ldots \ldots \ldots . . \ldots 1$

Andrea SommerlechNer, Spitäler in Nord- und Mittelitalien vom 11. bis zum Beginn des 14. Jahrhunderts . . . . . . . . . . . . . . . . . . . . . . . . . .

Edoardo BRESSAN, Hospitals and Social Care in the Early Modern Period. The Realisation and Discussion of the Welfare State in Italy

Thomas JUST und Herwig WeIgL, Spitäler im südöstlichen Deutschland und in den österreichischen Ländern im Mittelalter . . . . . . . . . . . . . . . . . .

Martin SCHEUTZ und Alfred Stefan WEISS, Spitäler im bayerischen und österreichischen Raum in der Frühen Neuzeit (bis 1800) . . . . . . . . . . . . . . . . .

Katharina Simon-Muscheid, Spitäler in Oberdeutschland, Vorderösterreich und der

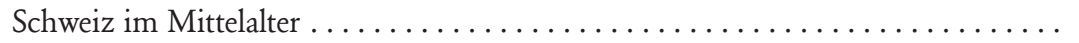

Ludwig OHNGemach, Spitäler in Oberdeutschland, Vorderösterreich und der Schweiz

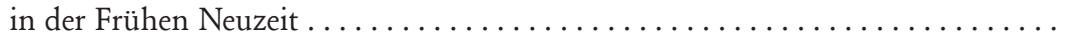

Kay Peter JANKRIFT, Hospitäler und Leprosorien im Nordwesten des mittelalterlichen Regnum Teutonicum. Unter besonderer Berücksichtigung rheinisch-westfälischer

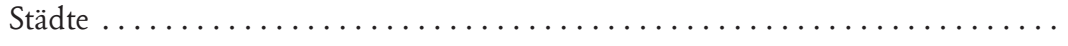


Frank HATJE, Institutionen der Armen-, Kranken- und Daseinsfürsorge im nördlichen

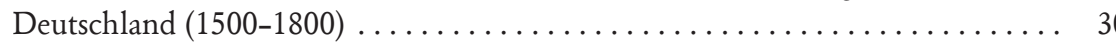

Petr SvobodnÝ, Die Spitäler in Böhmen und Mähren im Mittelalter und in der Frü-

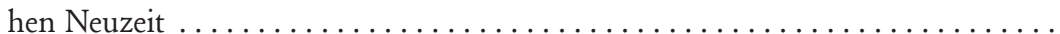

Ludmila HLavÁčKovÁ, Das Spitalwesen in Böhmen und Mähren vom Beginn des Dreißigjährigen Kriegs bis zu den Josephinischen Reformen (1620-1780)

Ivana EbelovÁ, Die Entstehung der ersten Krankenhäuser - Das Krankenhaus der Barmherzigen Brüder und der Elisabethinerinnen .................

Judit Majorossy und Katalin Szende, Hospitals in Medieval and Early Modern Hun-

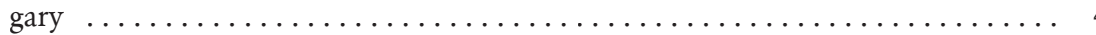

Lilla KRÁSZ, From Home Treatment to Hospitalisation: General Trends in the Development of Hungary's Hospital Network

Verzeichnis der Autorinnen und Autoren 476 


\section{Siglenverzeichnis}

\begin{tabular}{|c|c|}
\hline AASS & Acta Sanctorum \\
\hline Abh. & Abhandlung(en) (allgemein) \\
\hline $\mathrm{ACO}$ & Acta Conciliorum Oecumenicorum \\
\hline$A D B$ & Allgemeine Deutsche Biographie \\
\hline$A f D$ & Archiv für Diplomatik, Schriftgeschichte, Siegel- und Wappenkunde \\
\hline AfK & Archiv für Kulturgeschichte \\
\hline$A H C$ & Annuarium Historiae Conciliorum \\
\hline$A H P$ & Archivum Historiae Pontificiae \\
\hline AnBoll & Analecta Bollandiana \\
\hline Annales & Annales Économies, Sociétés, Civilisations \\
\hline$A \ddot{O} G$ & $\begin{array}{l}\text { Archiv für Österreichische Geschichte (bis Bd. 33: für Kunde österreichischer } \\
\text { Geschichts-Quellen) }\end{array}$ \\
\hline$A R G$ & Archiv für Reformationsgeschichte \\
\hline$A S I$ & Archivio storico italiano \\
\hline ASPP & Archivio della Società Parmense di Storia Patria \\
\hline ASV & Archivio Segreto Vaticano \\
\hline$A U F$ & Archiv für Urkundenforschung \\
\hline$B E C$ & Bibliothèque de l'École des chartes \\
\hline Bibl. Sanct. & Bibliotheca Sanctorum \\
\hline $\operatorname{BISI}(M)$ & $\begin{array}{l}\text { Bullettino dell'Istituto Storico Italiano per il Medio Evo (e Archivio } \\
\text { Muratoriano) }\end{array}$ \\
\hline BlldtLG & Blätter für deutsche Landesgeschichte \\
\hline BollSSS & Bollettino della Società storica subalpina \\
\hline BSSS & Biblioteca della Società storica subalpina \\
\hline $\mathrm{COD}^{3}$ & $\begin{array}{l}\text { Conciliorum Oecumenicorum Decreta, hg. von Giuseppe ALBERIGO et al. } \\
\text { (Bologna }{ }^{3} 1973 \text { ) }\end{array}$ \\
\hline CSEL & Corpus Scriptorum Ecclesiasticorum Latinorum \\
\hline$D A$ & Deutsches Archiv für Erforschung (bis 1944: Geschichte) des Mittelalters \\
\hline$D A C L$ & Dictionnaire d'Archéologie Chrétienne et de Liturgie \\
\hline$D B F$ & Dictionnaire de Biographie Française \\
\hline$D B I$ & Dizionario Biografico degli Italiani \\
\hline$D D C$ & Dictionnaire de Droit Canonique \\
\hline$D H G E$ & Dictionnaire d'Histoire et de Géographie Ecclésiastiques \\
\hline$D P$ & Documenta Pragensia \\
\hline$E C$ & Enciclopedia Cattolica \\
\hline EEA & English Episcopal Acta \\
\hline
\end{tabular}




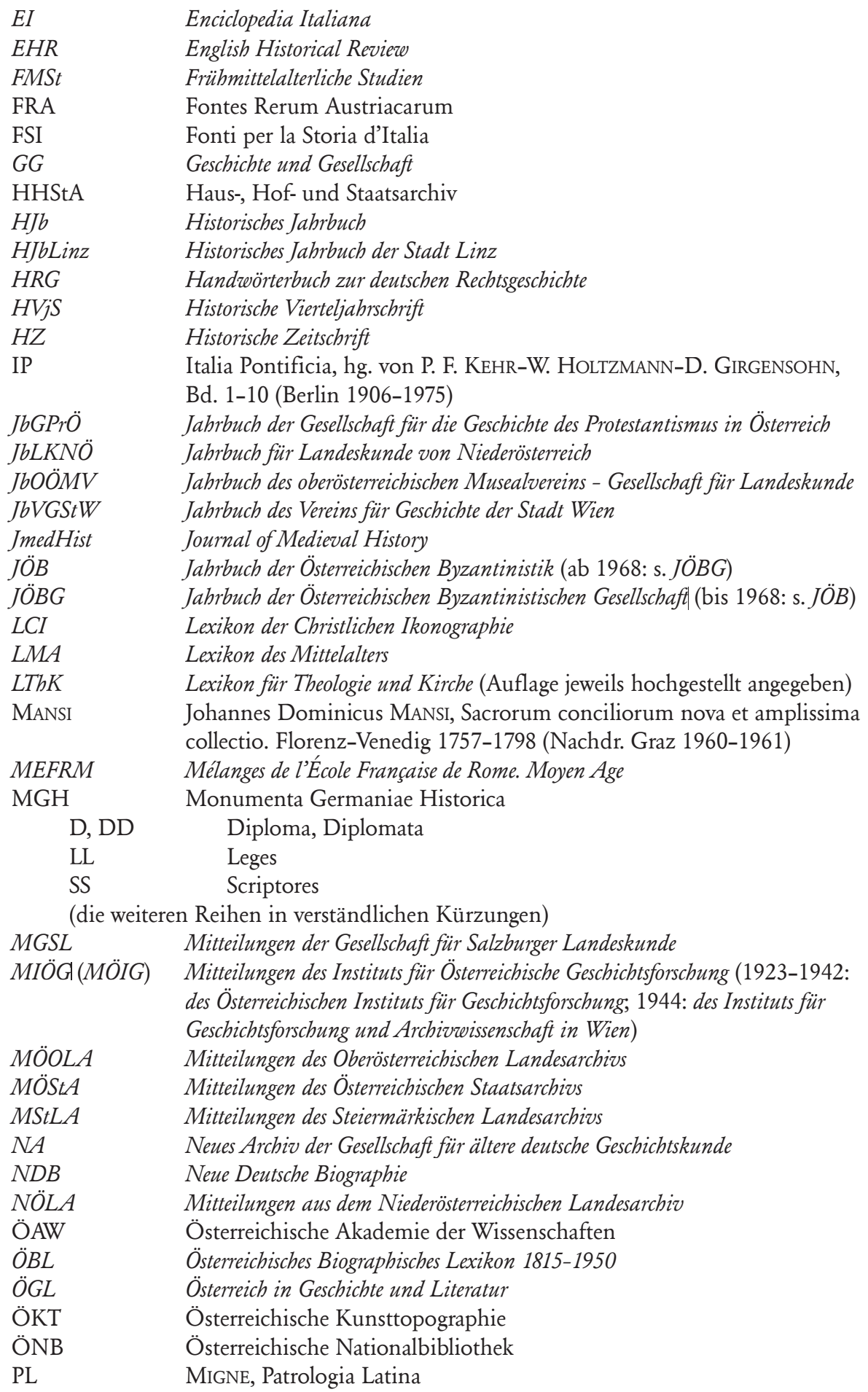




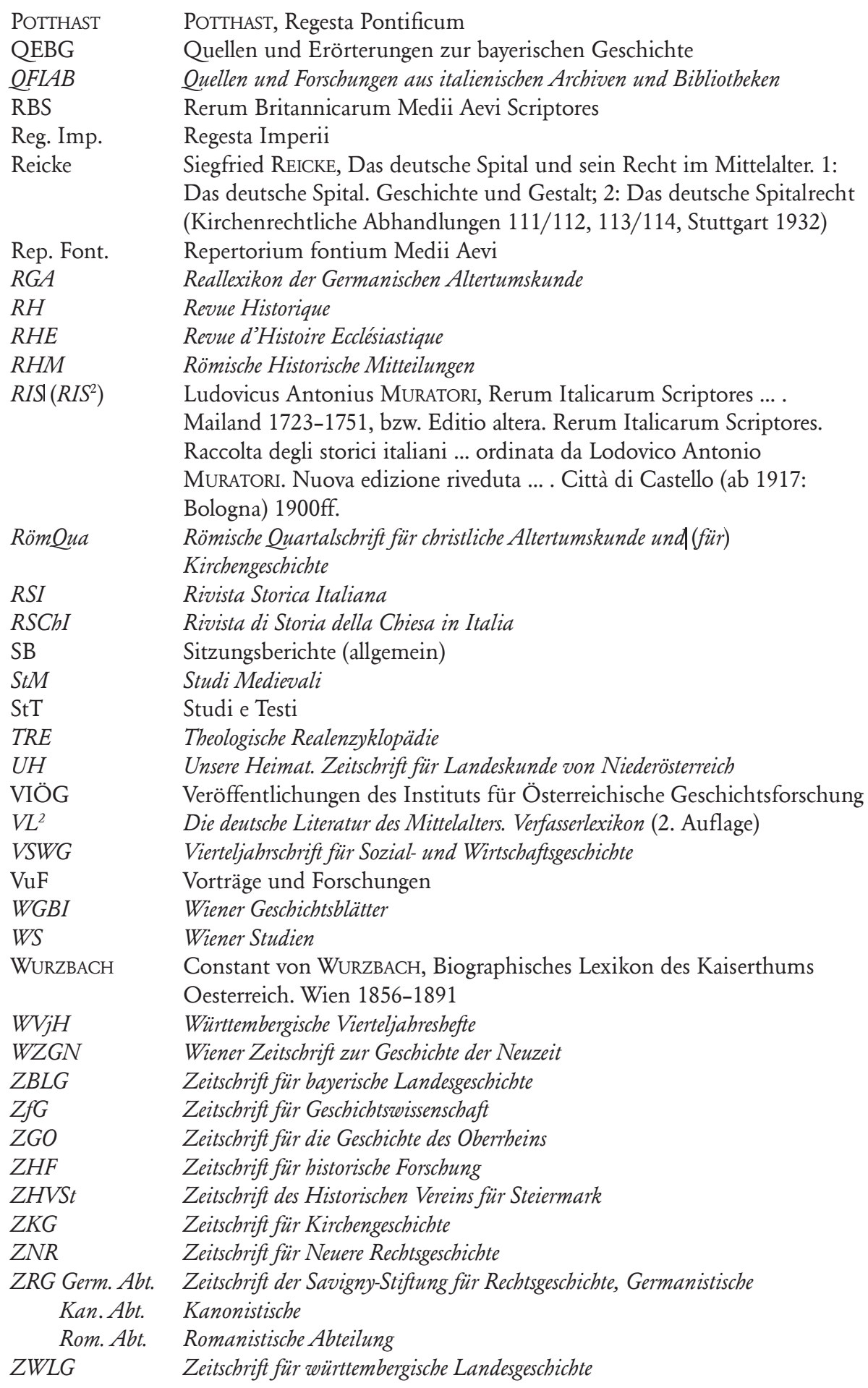





\title{
Hospitals and Social Care in the Early Modern Period The Realisation and Discussion of the Welfare State in Italy
}

\author{
Edoardo Bressan
}

In our modern-day culture there is a widely shared belief that our system of health care and our social institutions developed in a progressive, upward sense, moving from the ambiguity of a situation in which they were entrusted to charities and charitable institutions to the certainty of a situation in which health and social care is seen as a right of the citizen, a characteristic feature of the institutions of the Welfare State. From this point of view, the latter marks the final stage of a process that recognises the rights of the citizen - which, beyond being purely civil or political in character, are broadened out to include his private life. This process, in the way it intervenes in private life, moves from supplying aid simply to the poor to supplying aid to the worker and, finally, to supplying aid to the citizen ${ }^{1}$. According to this model, pre-modern systems of „charitable aid“ were replaced slowly but inexorably by systems which at first revolved around "public institutions“, and these were later followed by a system based on „social legislation“, a necessary premise for the ultimate development of the Welfare State.

However, it is only the Welfare State that truly succeeds in realising one of the main aims of nineteenth-century legislation, that of rendering society collectively responsible for risk and of the institutionalisation of social solidarity ${ }^{2}$, thus making it possible to move from a system based on charity to a system based on social security and to overcome the „negative social policies“ that marked preceding periods, as Jens Alber's now-classic study maintains. Yet there is still room for doubt here, as indeed even Alber's work seems to indicate ${ }^{3}$. Short of going into the recurrent dilemma of continuity versus change - by attempting, for example, to identify the remains of older charity-based systems within modern social systems and even within the hospital system itself - we need go no further than an examination of phenomena such as voluntary work, which really do seem more in tune with the thinking of the „ancients“ than of the „moderns“.

At this point it is worthwhile to pose questions about the nature of general change - a widespread, previously unthinkable transformation that involved the whole of Europe during the period stretching from the end of the ancien régime to the beginnings of the modern

1 See above all Thomas Humphrey MarSHALL, Citizenship and Social Class (Cambridge 1950); for a discussion of this point see Gian Primo Cella, Modelli di stato sociale, sviluppo, crisi, tendenze, in: Stato sociale e comunità solidale, ed. Sergio ONGER-Leonida TEDOLDI (Brescia 1998) 35-45.

2 Maurizio Ferrera, Modelli di solidarietà. Politica e riforme sociali nelle democrazie (Bologna 1993) 79.

3 Jens AlBer, Dalla carità allo Stato sociale (Bologna 1986) 17-20. 
period. A change that witnessed the arrival of a new historical subject in the field of health care and social security - the modern State. Many examples of this change can already be seen on the Italian peninsula over the course of the eighteenth century.

This change seems to derive, in effect, from the radically different terms in which the problem of promoting social welfare came to be viewed. This is highlighted, in both philosophical and political and institutional terms, by the Enlightenment debate. In fact, as Maurizio Bazzoli has underlined, this debate managed to bring together the idea of policing - typical of a State which had by then become intent on intervention and was attempting to take control of all areas of social life, under the influence of cameralism - with that of a philanth ropy capable of humanising a new kind of power no longer based on religion ${ }^{4}$. In this sense, social welfare was no longer one of the tasks of the Christian sovereign or the work of the self-organised social bodies of the ancien régime, but was linked to an unprecedented vision of the polis, of which the sovereign became the expression. And it is this that distinguishes the „Christian charity" of Muratori - with all of his appeals for renewal, mirrored by the establishment of a large number of hospitals and social welfare institutions, as well as by culture and the arts - from Ricci's ,social charity“. It is also the stance taken by the new laws governing social welfare in the late eighteenth and early nineteenth centuries ${ }^{5}$.

This is certainly not to say that the question of a subjective right to welfare was being posed. Yet at the same time there was a clear statement of the State's duty to respond to situations of need - and in particular to the need for health care - or at least to assure a response of some kind. This duty was clearly linked to the very different role the State had taken on, as well as to the way in which traditional social structures had been deprived of their authority, which in turn was linked to their own internal crises. What is more, this duty was also connected to the way the State itself had moved on from being a Police State to become a Welfare State (,Wohlfahrtsstaat"). This is, in fact, the point at which the latter came into being, bringing with it all the associated problems - and this concept of the state can, in fact, also be regarded as a vehicle for unprecedented forms of control, unknown in the society it replaced.

This transformation - imposed, one might say, as much by force of circumstance as by the force of ideas - appears to have been irreversible from the very beginning; nor, for that matter, would the legitimacy of state intervention ever again be called into question. On the other hand, the State did not necessarily have to intervene directly - supported inevitably by fiscal impositions, as in the case of the feared English and North European model of „legal charity" - but was also capable of intervening in the form of control over the institutions inherited from the past, the most important of which were the hospitals. These are the institutions that now went to make up the system of „public beneficence“, formally removed from the auspices of the urban aristocracy and the Church. And it is at this point, precisely in terms of what today would be called the relationship between State and society, that choices differed, even if later on the problem of how to re-establish a relationship with the situation „on the ground“, at the local, civic and ecclesiastical levels, would arise. Even though the clergy had been dispossessed of their earlier prerogatives, they would later find a way of participating in the system both politically and for the purpose of their own social legitimisation,

4 Maurizio BAzzoLI, Il pensiero politico dell'assolutismo illuminato (Firenze 1986) 387.

5 On this point, see Marco BIANCHINI, Bene comune, ragion di stato e felicità pubblica nella pratica assistenziale della prima metà del Settecento, in: La società bresciana e l'opera di Giacomo Ceruti. Atti del Convegno, Brescia, 25-26 settembre 1987, ed. Maurizio Pegrari (Brescia 1988) 249-259. 
by lending a hand in the management of the new welfare institutions. Local elites were also to be involved in management of the new social security establishment from the very outset.

This process was marked in many ways by a sense of continuity with the past, and in order to understand fully what it meant and the results it led to, we need to start with the situation as it was in Italy during the seventeenth and eighteenth centuries, for this was the period that exhibited the first signs of change, a change which was as political in nature as it was economic. The system of health care and social security appeared first, and without apparent contradictions, as a „system of charity“ inherited from the medieval respublica christiana, which developed during the lifespans of successive regional States on the basis of how much control they were able to exercise over local authorities and the clergy. The influence of the Catholic Reformation itself, as that of the Protestant Reformation in other parts of Europe, flowed through well-established channels. By the end of the Middle Ages, there had come to exist a vast network of charitable confraternities, often linked to the mendicant orders, as well as the first centralised offices offering welfare to townspeople, and, above all, the „ospedali maggiori“ and „monti di pietà“.

The individual institutions continued to be important, and the role they played was also clearly so. Their position was based on the traditional statutory autonomy guaranteed by an ius commune which had endured for centuries, and this was immediately reflected in the way they were administered. Administration functioned, with respect to both the executive bodies and to the source of their funds, on an entirely voluntary basis. It might be said that this mechanism was, in a sense, predetermined by the status quo: the elites supplied the hospitals and other social welfare institutions with the means to survive through donations and often quite sizeable bequests, and they also managed these institutions. The various noble families, in fact, took turns holding positions on the governing bodies. Their administration was shrewd and often remarkably efficient, and it was closely linked to the control of structures that were clearly very important in maintaining social equilibrium and allowing for social consensus. Bishops did try to interfere, but this was usually restricted; ecclesiastical privileges were brought to bear, however, in dealings with civil authorities. Generally speaking, these consisted of little more than the inclusion of representatives of the clergy in the governing bodies of the individual institutions, a measure which, however, was often neutralised by a sense of class solidarity between those monitoring and those being monitored - especially when one bears in mind that there was little or no effective government direction. In Milan, the administrative bodies of the Ospedale Maggiore and the other most important charitable institutions experimented with a „charitable governing body“, in which both the aristocracy and church commissioners worked together in an attempt, on the one hand, to legitimise and bring order to the institutions and, on the other, to seek to introduce religious reform and discipline ${ }^{6}$.

On the whole, however, just how important this network of institutions was becomes clear when we look at the number of people that were helped by it. If we accept the figures given by Brian Pullan, it means that 4 to 8 per cent of the total population received permanent aid through grants or shelter in institutions that were often halfway between hospitals and hospices; a second segment of the population (about 20 per cent) made frequent use of these institutions whenever they were in serious financial straits or whenever a crisis of a familial nature arose; a third group (70 per cent or more) made occasional use of the institutions, for example whenever there was a general social emergency or an urgent need

6 For a broad treatment of this area and a treatment of the voluminous literature that deals with it, see the papers collected in: Povertà e innovazioni istituzionali in Italia. Dal Medioevo ad oggi, ed. Vera ZAMAGNi (Bologna 2000). 
for health care. If the first two groups represented a more or less structural kind of poverty (even if the poor in these cases were not necessarily aided on a permanent basis), then the third represented poverty related to the economic cycle, the real element of weakness in premodern society. However, this does give us further confirmation of how far this system of protection was able to reach. In addition to the hospitals, for example, it offered an initial form of ensuring medical assistance and the free distribution of medicines, at least for those living in the towns?

This „system of charity“, which was driven by religious motivations and was also religious in the forms it took, certainly failed to reach the threshold of a fully-fledged system of social policy. But even though it did not juxtapose rights and obligations, it did turn out to be of great help in bringing society together and making sure it was balanced; it linked social security to the acceptance of an established ethical code rather than a political one, something not contradicted by the broad-based autonomy of the institutions. The „opera pia“ had a unified legal form, which was matched by the great variety of needs to which they were intended to respond. However, the services they offered were not specialised, in the sense that it was not important whether the people who worked for the system were technically qualified or not. The medical staff, such as they were, limited themselves to offering their services, but had no real power in the institutions they worked in, which remained in the care of the voluntary and „charitable“ governing bodies. Hospitals were charitable institutions, and by statute aimed at helping people who were both poor and infirm (pauperes infirmi), whose infirmity and illness were also caused by social factors. The rooms and transepts of the monumental buildings constructed in the fifteenth and sixteenth centuries continued to offer shelter to all and sundry, and at times they were not dissimilar from hospices for beggars and the disabled, orphanages, and various other types of shelter. Curing the sick had become one of the hallmarks of these institutions - but it was by no means the only one, nor was it the most important. University faculties and professional colleges continued to be the repositories of the „art of healing“, exercising a kind of corporative monopoly which made them still very distant from modern hospital practice ${ }^{8}$.

The characteristic features of the hospitals and charitable institutions of the ancien régime were autonomy and particularism. There was very little medical specialisation, nor were they specialised in terms of the kind of aid they offered. There were, it is true, some exceptions that differed from the norm in one way or another. These were now very distant from the undifferentiated kind of shelter offered by hospitals of medieval origin, the first examples of which had been institutions aimed specifically at offering shelter without offering health care; these were aimed either at specific social categories - the disabled, orphans and foundlings, single women and the „ashamed“ poor - or at the reduction of beggary. The first „beggars' hospitals“ appeared as early as the sixteenth century, but in the second half of the following century some governments on the peninsula gave the go-ahead, as we shall see, for the construction of „alberghi dei poveri“ („hostels for the poor“), thus ensuring that „the layabouts and vagabonds“ were once and for all kept away from hospitals, which were now starting to be considered more as the kind of institution we view them as today. Even if the situation remained essentially the same, the difference between social security and health

7 See Brian Pullan, Poveri, mendicanti e vagabondi (secoli XIV-XVII), in: Storia d'Italia, Annali 1, Dal feudalesimo al capitalismo (Torino 1978) 981-1047.

8 See Elena Brambilla, La medicina del Settecento: dal monopolio dogmatico alla professione scientifica, in: Storia d'Italia, Annali 7, Malattia e medicina, ed. Franco della Peruta (Torino 1984) 3-147. 
care was no longer simply a question of how the institutions themselves operated. This can be seen clearly in a number of hospitals which were established because of the specific need for health care. These began to specialise in offering cures for specific kinds of illnesses - there were hospitals for „incurable“ patients, for example, for patients affected by the terrible, littleunderstood disease of syphilis, as well as shelters for the insane and asylums for the blind and other types of invalids. These institutions were clearly designed for „specific“ purposes, and were characteristic of a new approach to poverty which, even if it still moved along traditional lines, was already subject to innovation'.

In the early years of the eighteenth century, the often grandiose, monumental Renaissance and Baroque Italian hospitals only took in „infirm“ patients - albeit those who were, in the words of Carlo Cattaneo, „needy ${ }^{" 10}$. This was a circumstance which, during a period not all that far off in the future, would yield its fruits, even if hospital practise made progress but did not yet anticipate clinical practise. However, during the first decades of the eighteenth century a heated debate on how to renew the system of health care took place, accompanied by clear improvements in medical and nursing care and the opening of a number of schools of anatomy and surgery.

Hospitals did not immediately experience the process of „clinicalisation“ necessary to make changes in approaching the problem of health care sustainable over the long term. However, teaching certainly did make its entrance into the wards of the „charity hospitals“ in Padua, Florence, Brescia, Parma, Modena, Milan, Pavia, Lucca and Naples. Although this took place amidst persistent closures, the foundations were being laid down here for, on the one hand, a breaking down of the divide between medicine and surgery which would allow for the scientific and therapeutic advances of the nineteenth century, and on the other, the replacement of the idea of a hospital as a place where patients were merely assisted with the idea of the hospital as a place where they were cured and helped to recover from a clearly identified illness ${ }^{11}$. The foundations for this process seem without doubt to lie in the eighteenth century and in certain ways in the preceding eras, as well.

What we are dealing with here is a complex, varied range of establishments including not just institutions for health care and hospitals, but also those which had previously differentiated themselves and which were now quickly transformed for the „large-scale isolation“ of the poor, beginning with the Hôpital général in fifteenth-century Paris ${ }^{12}$. The form of these social institutions - still regulated by a firmly established and well-balanced alliance between the organs of local government and the Christian prince - can be traced back to a mindset that emphasised discipline and hard work as a means of re-education. This is seen, in one sense, from a moral and religious point of view, as well as from a point of view which unquestioningly accepts the traditional status quo. The debates that took place in the early eighteenth century - an age already marked by a process of evolutionary change clearly capable of involving the institutions society uses for offering health care and aid in general - confirm that this mentality continued to persist ${ }^{13}$.

\footnotetext{
9 Brian Pullan, New approaches to poverty and new forms of institutional charity in late medieval and Renaissance Italy, in: Povertà e innovazioni istituzionali (cit. n. 6) 17-43.

${ }^{10}$ Carlo Cattaneo, Notizie naturali e civili su la Lombardia (Milano 1844) CIX.

11 For a broad treatment of this area, see Giorgio CosmAcinI, Storia della medicina e della sanità in Italia. Dalla peste europea alla guerra mondiale. 1348-1918 (Roma-Bari 1987).

12 The reference here is to Michel FouCAult, Storia della follia nell'età classica (Milano 1963). For a rather critical re-evaluation of the „mythe du grand renfermement“, see Pierre CHAUnU, Préface, in: Jean IMBERT, Le droit hospitalier de l'Ancien Régime (Paris 1993) IX-XII.

${ }_{13}$ See for example the papers collected in: Politica, vita religiosa, carità. Milano nel primo Settecento, ed. Marco Bona Castellotti-Edoardo Bressan-Paola Vismara (Milano 1997).
} 
Changes were in fact already taking place at the end of the previous century. The bestknown and most important example is to be found in the projects of the French Jesuit André Guevarre and his circle. The model for the „alberghi dei poveri“ that were founded on the Italian peninsula was the Parisian Hôpital général. This was true both for the more numerous institutions of the smaller towns and for those of the larger ones, such as in Genoa, Palermo, Naples and, not least, the Rome of Innocent XII, with the Hospice of San Michele a Ripa Grande. In many ways, this development formed a starting point for something new. The institutionalisation of the poor was viewed as a way of allowing the poor, through work and religious discipline, to reclaim their place in society in a fashion similar to that promoted by the first workhouses in England. These changes were destined to influence the spiritual literature of the period a great deal - albeit within a context that was clearly social in nature - and also had a strong influence on the thought of Muratori, the writer who was to change radically the way the social security system and the specific role of health care institutions developed, especially in the territories - including those in Italy - that were coming under the control or influence of Austria ${ }^{14}$.

In his treatise „Della carità cristiana in quanto essa è amore del prossimo“, the breadth and variety of his proposals emerged clearly ${ }^{15}$. And the meaning of charity, as Alberto Vecchi has underlined in his fundamental text on this point, was the „religious re-evaluation“ of an activity which is in itself ,secular", aiming at „public happiness“ - an intuition which is „extremely innovative“ for a text ,intended as a manual for those working in social institutions" such as those which Muratori himself was to promote, yet at the same time still very far from secularising the idea of charity. Muratori's reformism, even where it simplified and rationalised, still moved along traditional lines. It worked from a point of view which was at times critical of but nonetheless inspired by traditional religious preoccupations. This approach lent it authenticity and protected it from debatable ethical interpretations and any hint of possible corruption ${ }^{16}$.

Two points are of particular importance here. These could be considered, in practical terms, to be the twin pillars of his proposal for reform, and they aimed at overcoming the twin dichotomy characteristic of existing systems - the dichotomy between individual almsgiving and collective action and the dichotomy between the needs of the population in general and the trend towards specialisation of the institutions themselves. This re-affirmation of the spiritual significance of alms-giving was in fact linked to the „compagnie della caritä. The task of these was to identify where there were people in need and what their needs were and act as the motor for proposing ways of meeting those needs and suggesting improvements to services that already existed. Membership was free, the work was voluntary, and potentially they were open „not only to the rich, not only to the powerful, the nobles, and the literati, but to everybody, of whatever class or condition" ${ }^{\text {"17. }}$.

${ }^{14}$ On these points, see Mario RosA, Forme assistenziali e strutture caritative della Chiesa dal '500 al '700, in: Stato e Chiesa di fronte al problema dell'assistenza (Roma 1982) 89-118; Luigi FIORANI, Religione e povertà. Il dibattito sul pauperismo a Roma tra Cinque e Settecento. Ricerche per la storia religiosa di Roma 3 (1979) 43-131; Flavio BARONCElli-Giovanni Assereto, Sulla povertà. Idee, leggi, progetti nell'Europa moderna (Genova-Ivrea 1983).

15 Ludovico Antonio MurATORI, Della carità cristiana in quanto essa è amore del prossimo, trattato morale (Venezia 1724). The first edition of this work appeared in Modena a year earlier.

16 Alberto VeCCHI, L'itinerario spirituale del Muratori, in: L. A. Muratori e la cultura contemporanea. Atti del convegno internazionale di studi muratoriani, Modena 1972 (Firenze 1975) 181-223, cit. 208s.

17 MurATORI, Della carità cristiana 166 (,,non ai soli ricchi, non ai soli potenti, nobili, e letterati, ma a tutti, di qualunque censo e condizione"). See VECCHI, L'itinerario spirituale 205: Muratori's experience as a priest was of great importance here, if it is true that ,it was intended as the literary fruit of the foundation of the Compagnia della Carita“. 
The idea of more specialised kinds of institutions and services became a vital reference point, ranging from health care to social services. Perhaps for the first time, and in very clear terms, there was recognition of the central importance of hospitals and the system of health care in general, including home visits and the free supply of medicine: „The most important thing of all is to provide for the needs of the poverelli infermi. The vision of poor people confined to their beds is a great catalyst for Christian pity. One does not know if the greater ill is the disease of the body or their poverty itself. Distressed by fevers or by other ills, which are very likely caused by the poor constitution of human nature, these unhappy souls find themselves without doctors and without medicines: this may appear to be of little negative consequence to those who are, to their disgrace, persuaded of the impotence of the medical arts, yet, in the judgement of all who are wise, is a true calamity. Experience does not lie, and it shows us that medicine and surgery, prudently applied, may in no few cases save from the final disaster the lives of men, as well as shortening the duration of their ills, and free them or preserve them from various infirmities which, without timely intervention of remedies, would betake themselves of their bodies, or, if they were already overcome, would not leave them be. In addition to which it is also a real relief for the languishing poor, and a sensible comfort to their kin, to see that at least some attempt is being made to cure them. An even greater weight is added to the miserable condition of ill people such as these by their poverty. Earning a living through manual work, or even procuring it by requesting alms, is now impossible for them. Hence they are obliged to live their days with a thousand hardships laden upon them, and to consume that little that they already have in their homes, such that, even when they are once again in health, very often they remain even poorer than they were before, and without sustenance of any kind. The situation is made even worse if they are the heads of families with children, who see in the life and work of their dear and necessary father the source of all sustenance, and who may, be he gone, lose everything. Which explains how fitting it is to the nature of man, and much more for the heart of those who are brought up in the school of Christ, to commiserate thoroughly with all of those who find themselves without that great good and comfort of their poor state, namely their health. It is therefore a necessity to aid them in such a bitter period in the best way possible ${ }^{\text {"18 }}$.

18 MURATORI, Della carità cristiana 184s. („Primieramente sopra ogni altra cosa esige provvedimento il bisogno de' poverelli infermi. Grande incitamento alla misericordia cristiana il mirare la povera gente confinata in un letto, a cui non si sa allora se faccia maggior guerra il malore del corpo, o pure la stessa povertà. Crucciati dalle febbri, e da gli altri mali, che facilmente scaturiscono dalla misera costituzione dell'umana natura, truovansi gl'infelici senza medici, e senza medicamenti: il che sebben poco danno parrà a chi è troppo sconciamente persuaso dell'impotenza dell'arte medica, pure nel giudizio de' saggi è una vera sciagura. Non mentisce la esperienza, facendoci vedere, che la medicina, e la cirugia prudentemente adoperate possono in non pochi casi salvare dall'ultimo tracollo la vita de gli uomini, non che abbreviare i lor mali, e liberarli, o preservarli da varie infermità, le quali senza l'opportuno soccorso de' rimedj o s'impadronirebbero de i loro corpi, o impadronite che fossero, più non se ne partirebbono. Oltre di che è anche un real sollievo de' poveri languenti, e un sensibil conforto a i loro congiunti il vedere, che almeno si fa quel tentativo che si può per guarirli. Peso anche maggiore aggiunge alla miserabil condizione di simili infermi la povertà. Guadagnarsi il vitto coll'opera delle mani, o pure procacciarselo con chiedere la limosina, ad essi è allora impossibile; e però eccoli necessitati a condurre que' giorni fra mille stenti, e a consumare quel poco che si trovano avere in casa, di maniera che quand'anche risanino, restano bene spesso, di poveri che erano, poverissimi, e derelitti affatto di sostanze. Peggio poi, se si tratta di capi di famiglie con figliuoli, che nella vita e nelle fatiche del loro caro e necessario padre veggiono consistere l'erario tutto de' propri alimenti, e possono, mancando lui, perdere tutto. Il perché quanto è conveniente alla natura di chi è uomo, e molto più al cuore di chi è allevato nella scuola di Cristo, il concepire una viva commiserazione per tutti coloro, che si truovano privi di quel gran bene e conforto del povero loro stato, cioè della sanità; altrettanto è necessario il sovvenirli in così aspra congiuntura nella miglior maniera possibile"). 
The importance of medical or health care, which is by no means to be taken for granted, is underlined in both the „ways" in which „mercy can be shown to the poor who are sick“, namely that of „aiding them in their own homes“ and that of „allowing them entry into public hospitals". The latter alone knew how to extend to them „the charity of the followers of the Cross", and without doubt were the pride of every Christian city, but perhaps there were simply not enough of them, as Muratori hints in a passage of great importance: „However, should a city be without one, it will be an indispensable task of the compagnia della carità to ensure that they are founded, or that those that have been abandoned are brought back to life. Heaven and earth must be moved to do this, and it must be preached and insisted on heart and soul, and the need must be made known, and the glory that may come to the country must be made apparent, and what is more important the glory that will come to holy religion and the good God, the great lover of the poor, and in holy love the Father of us all. It is possible, it is true, to meet the needs of the poor and sick in other ways; but for all that, the most commendable and useful way is to bring them together in hospitals, and there to cure them, which can be easily done with the aid of surgeons and other hospital workers and assistants, precisely because of the ease of finding everything in the same place and available to anyone who has need of their help" ${ }^{\text {19 }}$.

Muratori turns his attention to all areas of social need, from the problems of infants to those of the old, from school to the family, from „monti di pieta““ to prisons. Not by chance, the solutions he proposes all move in the direction of prevention and cure, with the responsibility for these firmly in the hands of the public authorities, the associations, the institutions and those involved in voluntary work. For Muratori, it is only at this point that the problem of „pubblici ospizi de'poveri“ („public hospices for the poor“) can be posed. He does not conceal the fact that he is slightly sceptical of these. He also refuses the idea of prohibiting begging in general, preferring instead the idea of assigning work to the individual. Help to be given to poor people specifically, unlike the organisation of health care, is something that is better supplied through a network of local services ${ }^{20}$. There can be no doubt that Muratori's position takes up once more the basic ideas of the scholastic philosophical tradition, even if he clearly modifies these. As he writes in the pages of his „Trattato“, it is part of the „nature of man as a social creature“ to provide an answer to ,inequality“ and „need“; we must „believe we are beholden, by the laws of nature, to meet the needs of other men and give relief, for our part, to help others and by way of restitution“21.

19 Ibid. 186 („Tuttavia, quando mai ne scarseggiasse una città sarà un impiego indispensabile della compagnia della carità il fare in guisa che si fondino, o risorgano di nuovo quei che fossero scaduti. A questo fine s'ha da muovere cielo e terra, e predicare, e insistere animosamente, con farne ben conoscere la necessità, e mostrare la gloria, che può venirne alla patria, e quel che è più, la gloria che ne ridonderà alla sacrosanta religione, e all'ottimo Dio, sì grande amatore dei poverelli, e padre di tutto il santo amore. Si può, è vero, soccorrere in altra maniera alle necessità de' poveri infermi: con tutto ciò la più lodevole e la più utile si è quella di radunarli ne gli spedali, e di quivi assistere alla loro cura, che facilmente si eseguisce da' cerusici, e da altri operai ed assistenti, appunto per comodità di trovar unito e alla mano chiunque è in bisogno del loro soccorso").

${ }^{20}$ Ibid. 219s. On ,innovative movements of a broader type“ characteristic of Muratori’s treatise, see Daniele MENOZZI, Chiesa poveri società nell'età moderna e contemporanea (Brescia 1980) 46s.

${ }^{21}$ MURATORI, Della carità cristiana 4 („,crederci tenuti per legge di natura a ristorare le necessità dell’altro uomo, e a seminare dal canto nostro benefizi, e a titolo di restituzione"). See Cesare MozzARELLI, Introduction, in: Ludovico Antonio Muratori, Della pubblica felicità oggetto de' buoni principi, ed. Cesare MozzARELL (Roma 1996) VII-XXXIX, at XXIIs.: „Muratori is clearly aware of the decline of political Aristotelianism in all its various forms and of the ,way of life" of the aristocracy and other classes that had associated themselves with it in the Europe of the ancien régime, but because of his Christian faith he continues to insist that an individualistic, egoistic attitude 
In these decades there are many examples of the foundation of charitable institutions, or at the very least of bequests which would later give rise to them: hospices, and above all hospitals, often in smaller towns or rural areas, even if the latter are not necessarily definable as such in the modern sense of the term ${ }^{22}$. Just how close Muratori's proposals are to the thought of the preceding period becomes clear in the central role he gives to the work of charitable associations. It is even possible to detect growth in this area; there is more sensitivity to the needs of the less fortunate, and this in turn leads to greater participation in the associations and to the consolidation and foundation of other charitable brotherhoods, often dedicated to voluntary hospital work ante litteram, as is amply documented in the case of Milan ${ }^{23}$.

At the beginning of the eighteenth century it was, in fact, Milan's Ospedale Maggiore which once again showed how remarkably capable it was of renewing itself, both in terms of medical practise and in terms of hospital administration. At that point, it was the hub of a well-developed network of institutions spread throughout the region. Yet despite its central role, it was inseparable from all the other structures in the network, which were of the most varied kind, from educational establishments to institutions set up to cater for the needy to other centres of health care, right down to the supply of aid for poor families and medical assistance at home. In many senses, this was the heritage of a model of self-government which has always been attentive to the need to maintain social equilibria, supported by a Church which, from Carlo Borromeo down, was deeply rooted in the social fabric of the city. Yet, like a number of other Italian cities that shared the same characteristics, it was not closed in on itself. Rather, it was open to innovation, albeit innovation bound by the limits already established in earlier times.

This is the background against which the far-reaching reforms of the system were then carried out by the Italian states, and in particular by those regions under the governance of the Habsburg monarchy. Not coincidentally, these reforms were to adopt many of the traditional characteristics of the system as it already was, but this time they were filtered through the reformist approach of Muratori, even if the politics and culture of the area had now changed. As we might expect, there was some resistance on the part of the governing bodies of both the hospitals and the charitable associations. What allowed these reforms to be pushed through, however, was the considerable political weight of the Crown, which imposed itself on local, associative and ecclesiastical powers. For some time, in fact, the State had started to take charge of all the most important areas of social life, and this process was now well under way. These early reforms, however, were later to be followed by other, more decisive measures - measures destined to change radically the administration of the hospitals and charitable organisations.

These provisions took a number of different forms, depending on the different situations of the Italian states and, at times, the different ways in which the health care systems were regulated within them. Generally speaking, however, they moved in the same direction,

can never become a stable, widely-shared basis for society as a whole“. His response to it was not „an isolated one or one that arrived late; on the contrary, it was based on considerations different from those to be found in France or England. Rather, it was closer to the ideas to be found in Germany, which were based on the idea of a natural law at the basis of human society and insisted on the idea that a love of God would manifest itself in the form of a duty to love others".

${ }^{22}$ For these examples see Edoardo BRESSAN, Carità e riforma sociale nel Settecento lombardo: in Politica, vita religiosa, carità (cit. n. 13) 235-255, cit. 235s.

${ }^{23}$ For a number of considerations on this point, see Danilo ZARDIN, La città e l'ospedale. Alle radici di un „volontariato“ cristiano. Diocesi di Milano. Terra ambrosiana 28 (1987) 63-73. 
from the imposition of effective government direction of the system, with rigid control imposed particularly at the economic and financial levels, to the appointment of government functionaries in place of the old administrative bodies. It is worth remembering that this was a change of a basic, irreversible kind, a change later to be consolidated by the revolutionary and Napoleonic governments - which then extended it to other territories which had not yet experienced this kind of reform. Essentially, it was also the line followed by the legislation of the Restoration period.

The most important change that was brought about was the way ecclesiastical prerogatives in the area of charitable works everywhere were challenged. Not surprisingly, this is most apparent in those areas where absolutist rule had been at its most „enlightened“, due either to dynastic change or influences from beyond the Alps or the influence of developments in juridical thought. In Lombardy, which was ruled by the Habsburgs, the government of Maria Theresia had already placed all the „luoghi pii“ („religious charitable institutions“), which for a century or more had been run privately, under government direction. The property and estates of the institutions were guaranteed, but any change or „extraordinary “ use of them was subject to government approval. Joseph II took the next logical step in making the system of health and social care part of the public domain. He placed the administration of the hospitals under direct royal control and created a new professional figure - that of the medical director, whose duties were linked to those of the new health care establishment. A coherent medical policy was adopted, and on the basis of this the hospitals embarked upon an initial process of decentralisation. Hospitals were set up outside the city centres and parish doctors appointed throughout the territory. The process of reform at the Medical Faculty in Pavia was completed, with great attention being given to clinical medicine and surgery. Likewise, clinical medical practices became the norm at the Ospedale San Matteo, and the professional training of doctors came to be regulated by the political authorities.

Hence change within the political and institutional spheres and medical and scientific progress now seemed to be inseparable from one another. Not surprisingly, then, even the most important hospital of Austrian Lombardy, Milan's Ospedale Maggiore, could not help but be involved in a project of reform imposed from above, sponsored as it was by Prince Kaunitz himself. In 1767 a new administrative body, the „Giunta economale“, was endowed with extensive powers over the administration of hospitals and charitable institutions. At the same time, government inspections were introduced, and these two measures broke with centuriesold tradition. The „Capitolo“, the old administrative organ of the hospital, tried in vain to oppose these decisions, urging the Cardinal, Archbishop Pozzobonelli, to introduce a project of reform that would have safeguarded the autonomy of the hospitals, but the radical Josephine provisions of 1784-1785, destined to change irreversibly the face of social and health care in the city, went still further, dissolving the „Capitolo“ entirely and appointing a governor and a medical director. With the widespread reaction to the Josephine reforms, Leopold II decided in 1791 to revert to the preceding system, but this turnaround was at best only partial ${ }^{24}$.

${ }^{24}$ For these references, see Ada ANNONI, Assistenza e beneficenza nell'età delle riforme, in: Economia, istituzioni, cultura in Lombardia nell'età di Maria Teresa, 3: Istituzioni e società, ed. Aldo DE MADDALENA-Ettore RotelLI-Gennaro BARBARISI (Bologna 1982) 897-990; Carlo CAPRA, Il Settecento, in: Il Ducato di Milano dal 1535 al 1796, ed. Domenico SELLA-Carlo CAPRA (Torino 1984) 151-663, cit. 386s.; Antonia PASI, Tra continuità e rinnovamento: il San Matteo dalle riforme settecentesche alla metà dell'Ottocento, in: L’Ospedale San Matteo di Pavia. Fatti e problemi del passato, ed. Dante ZANETTI (Pavia 1994) 105-136. For an analysis of the laws passed to deal with this area, see Vittorio Brondi, La beneficenza legale, in: Primo trattato completo di diritto amministrativo italiano 8, ed. Vittorio Emanuele ORLANDO (Milano 1905) 1-379, cit. 193s. 
The Grand Duke of Tuscany, brother and successor to Joseph II, inaugurated a series of reforms which were just as far-reaching. He reduced the power of entrenched ecclesiastical influence and replaced the ancient administrative body of the hospitals, the „spedalinghi“, with a commissioner. Hospital reorganisation, therapeutic specialisation, and clinical training within the hospitals themselves proceeded at the same rate in Tuscany as they did in Lombardy. In the state of Parma, health care institutions were secularised very early on. This was triggered by an enlightened approach modelled on that of France. During the same period, the government also took control of the health care system and centralised hospitals in Modena, a state that was soon to embark on the radical reforms of Ricci. There was less direct intervention on the part of the state in Piedmont. However, procedures for monitoring all charitable and welfare institutions of the kingdom were put into place, entrusted to the local authorities and the local „Congregazioni di caritä“. With largesse that was at times remarkable, the Piedmont state also financed advances in the clinical and medical fields. The same can also be said for the Republic of Venice, in which a secular judiciary and the autonomy of research institutions were fairly important, even when one considers the role played by patrician families and the lack of state intervention ${ }^{25}$.

Many institutions were used for the purpose of exercising control over certain sections of the population - this was the case, for instance, with the voluntary work imposed on „beggars hospice“ inmates, who were prohibited from begging, and with institutions set up for the disabled and the „impotenti“. At the same time, however, a series of unquestionable advances took place, and this is in line with a coherent pattern of the bourgeois societal rationalisation, called for by those intellectuals and doctors that later would be called "Jacobins“, but also pursued in reality by many governments. In fact, however, this trend was a continuation of a number of developments from the preceding period, transforming workhouses into a means for giving beggars a way of making a living, often through work supplied at home, an option these institutions often freely resorted to, along with intervention by the police - who imposed imprisonment.

Clinical practice became a more stable part of hospital life beyond university teaching itself, while, in the light of the great transalpine debate „sur les hôpitaux“, the conditions were created for large-scale architectonic restructuring, improvements in hygiene and sanitary conditions, and more efficient economic management. Once again, Milan is emblematic here. Medicine continued to develop throughout the territory, and if little could be done to deal with the new pandemics that struck the lower classes, results of no little significance were obtained in rural areas via vaccinations against smallpox. The use of modern medicine became more widespread and, at the same time, medical practise became more precise. This led to certain ambiguities within the system. For example: an end was put to the isolation of lunatics and other kinds of disabled people, but at the same time, a network of „hospices“ was set up in which the scientific approach was clearly a secondary consideration when compared to the need to control and discipline the inmates ${ }^{26}$.

The Josephine reforms themselves, taken as a whole, exhibited a certain amount of wavering between the old and the new, and the need for both continuity and change can be

\footnotetext{
${ }^{25}$ For an accurate summary of this area, see Alessandro PASTORE, Il problema dei poveri agli inizi dell'età moderna, in: Povertà e innovazioni istituzionali (cit. n. 6) 185-205, and Stuart Woolf, The „transformation“ of charity in Italy, 18th-19th centuries, in: ibid. 421-439; and, more generally, Arnaldo CHERUBINI, Dottrine e metodi assistenziali dal 1798 al 1848. Italia - Francia - Inghilterra (Milano 1958) 13s.

${ }^{26}$ Cosmacini, Storia della medicina (cit. n. 11) $257 \mathrm{~s}$.
} 
clearly felt. This can be seen especially in the forms taken by alms-giving and shelter; these clearly reflected the characteristic religious background that would mark Austrian legislation on the matter for a long time, but which nonetheless was an essential component of these reforms. In fact, it must be borne in mind that, as has been noted with respect to „Staatskirchentum and the Enlightenment", „Josephine caritas" places particular emphasis on „a greater involvement of the church in the enlightened state of wellbeing', in the realisation of the Rationalist postulate of ,the greatest possible happiness for all'. This represented an attempt to give substance to an essentially Christian ethical position, something which had been in part ignored up to this point. This was a way of introducing ethics into the system, guided, however, by the state - of an ennobling of morals, inspired by a church that had been reformed along Enlightenment and Jansenist lines, renouncing the abuses of the Baroque period in the name of the promotion of a better life here on Earth and salvation in the life to come“27.

The same is true of the way in which health care and social security were made part of the public domain. They revolved around a model which was that of the confraternities of the past, similar to the „Armeninstitut" created for the first time in Bohemia at the end of the 1770s by the Count of Buquoy, the same man who was called upon by Joseph II a few years later to organise the Institution for the poor in Vienna under the control of the "Stiftungshofkommission". This is exactly the same model introduced during the same period in Austrian Lombardy, and it was destined to influence greatly the laws and institutions of the Napoleonic era, as part of a great effort - the result of an ethical point of view based on the needs of society - to reduce the number of poor. However, on both sides of the Alps this trend, contradicting the principles which had inspired it, collided with the end of the widespread associationism which had established itself during the Baroque era and its forced reduction to a single state-controlled charitable confraternity within each parish, such that in a certain sense the distribution of charity became the end point of the public welfare system as a whole, supporting hospitals, orphanages, hospices and workhouses - in short, a whole network of institutions which was thus strengthened and, if necessary, created ex novo ${ }^{28}$.

Over and above the direct objectives of this political and ideological scheme - which aimed at ensuring that the Church was kept under careful check by the state, which had decisive power to intervene in "spiritual affairs“ and the development of society in general, as Giorgio Rumi has underlined ${ }^{29}$ - it is worth noting how local and ecclesiastical authorities were integrated into the overall plan of the reforms. This was made possible precisely because during the eighteenth century, there existed an ever-increasing openness to society and social problems; and it was precisely from religious and civil society that men and resources continued arriving to take part in the new administrative organs, who were called upon to carry out, especially in the case of the hospitals, a task as important as it was difficult. As early as the initial years of the nineteenth century, new voluntary organisations were at work amongst the sick, at the Ospedale Maggiore in Milan and in many other institutions, while the be-

${ }^{27}$ Heribert RAAB, Staatskirchentum e illuminismo nei territori dell'impero a governo laico. Teresianismo e giuseppinismo, in: Storia della Chiesa, ed. Hubert Jedin, 7: La Chiesa nell'epoca dell'assolutismo e dell'illuminismo (Milano 1978) 543-567, cit. 543

${ }_{28}$ Marco Giacomo BASCAPÈ, Gli interventi teresiani e giuseppini contro il pauperismo. Dai progetti degli anni cinquanta all'Istituto generale delle elemosine, in: Cultura, religione e trasformazione sociale. Milano e la Lombardia dalle riforme all'unità, ed. Marco BONA CASTELLOTTI-Edoardo BrESSAN-Camillo ForNASIERI-Paola VISMARA (Milano 2001) 109-138.

29 Giorgio Rumi, Religione e società nella caduta dell'antico regime (1796-1859), in: ibid. 39-43. 
quests and donations flowed once more. Nor did the administrators' level of commitment to their duties let up ${ }^{30}$.

For Italian hospitals, the seventeenth and eighteenth centuries were a period of fundamental importance. This period first of all brought to a close the process that had begun with the reforms that heralded in the modern era - with the creation of the „ospedali maggio-

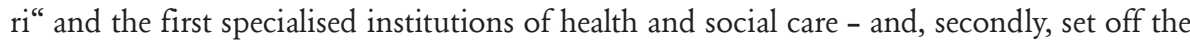
„revolution in clinical practise“ that was to follow. At an ideal level at least, hospitals were no longer shelters providing care for all and sundry. At the same time, the foundations were laid for the transformation that was to come, a transformation which would change the health care system into a machine à guérir, linked up to a network of local doctors tied in with health practitioners that were now free from ties to the corporative bodies of the ancien régime.

Prior to this, however, a distinction had been made between help for the sick and help for the poor. Special institutions for the latter had been set up, and society had become better able to identify, even as early as Muratori, the special nature of hospital care and health care, now destined to play a role of central importance in terms of the way social policy acted upon society itself. On this point the state - which simultaneously policed society and assured the welfare of its citizens - took on a new role, resolving the situation by replacing local and ecclesiastical bodies, and introducing all those problems and grey areas which, from the very beginning, accompanied the process of modernisation destined to take place in the eighteenth and nineteenth centuries.

And yet the hospitals and welfare institutions of the ancien régime, far from being static, became part of the basis of the new regime, entering into a close, complex relationship with society and the Church at a local level. These are points to which eighteenth century reformism, even - and in certain senses above all - in Habsburg territories, paid careful attention. They also helped to keep the hospitals at the centre of the life of the cities, of the towns and villages, and throughout the territory. In this way, a more modern conception of hospitals as „luoghi della cura" („places of cure") became one of the main aims of public life.

${ }^{30}$ On these developments, it is important to take into account Giorgio RuMI, Lombardia guelfa 1780-1980 (Brescia 1988) 117-131. 